\title{
The resource curse and child mortality, 1961-2011
}

\author{
Simon Wigley \\ Department of Philosophy, Bilkent University, 06800, Bilkent, Ankara, Turkey
}

\section{A R T I C L E I N F O}

\section{Article history:}

Received 31 July 2016

Received in revised form

10 January 2017

Accepted 22 January 2017

Available online 23 January 2017

\section{Keywords:}

Resource curse

Under-five mortality

Human capital

Panel data

Country fixed-effects

\begin{abstract}
A B S T R A C T
There is now an extensive literature on the adverse effect of petroleum wealth on the political, economic and social well-being of a country. In this study we examine whether the so-called resource curse extends to the health of children, as measured by under-five mortality. We argue that the type of revenue available to governments in petroleum-rich countries reduces their incentive to improve child health. Whereas the type of revenue available to governments in petroleum-poor countries encourages policies designed to improve child health. In order to test that line of argument we employ a panel of 167 countries (all countries with populations above 250,000) for the years 1961-2011. We find robust evidence that petroleum-poor countries outperform petroleum-rich countries when it comes to reducing under-five mortality. This suggests that governments in oil abundant countries often fail to effectively use the resource windfall at their disposal to improve child health.
\end{abstract}

() 2017 Elsevier Ltd. All rights reserved.
There is now a large literature that purports to show that petroleum wealth has an adverse effect on a country's political, social, and economic well-being. More specifically it is argued that oil and natural gas abundance strengthens autocratic governments, undermines the effectiveness of governmental institutions, increases the likelihood of civil conflict, reinforces gender inequality, and frustrates economic growth (Ross, 2015; van der Ploeg, 2011). This suggests that the discovery of substantial oil and gas reserves may, paradoxically, represent a curse rather than a blessing for a country.

In this article we examine whether the so-called resource curse extends to the health of children, as measured by the probability of dying between birth and age five. Child mortality provides an indicator of the health status of the most vulnerable members of society. It also provides an indicator of the well-being of the poorest members of society. That is because premature mortality amongst the youngest primarily afflicts the poorest members of society (de Looper and Lafortune, 2009; Yazbeck, 2009). Thus, child mortality allows us to examine the impact of petroleum wealth both on the well-being of children and, indirectly, the well-being of the poorest.

It is also worth noting that child mortality often results from causes that are comparatively easier and less costly to prevent or treat (e.g. through access to clean water, oral rehydration, antibiotics, ante and post-natal care etc.). Of those children from around the world that died before five years of age in $201351.8 \%$ died of infectious causes, with the largest shares caused by pneumonia

E-mail address: wigley@bilkent.edu.tr.
(14.9\%), diarrhea (9.2\%) and malaria (7.2\%) (Liu et al., 2015). Effective interventions are available for all three diseases. That suggests that child mortality should be responsive to public policy-making. Moreover, it indicates that governments with access to abundant oil revenues have more than sufficient resources to tackle child mortality. Indeed two studies have presented evidence suggesting that oil wealth does not adversely affect the ability of governments to reduce child mortality (Cotet and Tsui, 2013a; Ross, 2012, pp. 196-197).

In what follows we argue and present evidence in support of the view that resource-poor countries outperform resource-rich countries with respect to child health. We contend that the type of revenue available to governments in resource-rich countries reduces their incentive to improve child health. Whereas the type of revenue available to governments in resource-poor countries, encourages policies designed to improve child health. The non-tax revenue available to the former means they need not seek the progrowth benefits that flow from improved child health. Whereas the tax revenue that the latter depend on means they must seek the pro-growth benefits that flow from improved child health.

In order to test that line of argument we employ a panel of 167 countries (all countries with a population greater than 250,000 ) for the years 1961-2011. We find evidence that oil wealth is positively associated with under-five mortality after controlling for potentially confounding factors. This suggests that governments in oil rich countries often fail to effectively use the resource windfall at their disposal to improve the well-being of children and, more 
generally, the poorest. The results are robust to the inclusion of fixed country and year effects, lags and instrumental variables to mitigate potential endogeneity, alternative measures of oil wealth and child health, as well as the use of multiple imputation to estimate missing data.

\section{The paradox of plenty}

Why is oil wealth a curse rather than a blessing? One of the key reasons is that oil and gas reserves provide governments with a source of revenue that does not require the collection of taxes from the population at large. This increases the likelihood that political leaders will remain in power and reduces the incentive for governments to invest in human capital.

The standard explanation as to why oil wealth prolongs nondemocratic rule is that hydrocarbon revenues enable autocratic leaders to buy the support of their backers without having to impose taxes. By contrast autocratic leaders without access to oil revenues must levy taxes to finance the dispersal of benefits to the regime's supporters, with the attendant risk that those who are taxed may demand greater representation (Levi, 1989; Mahdavy, 1970). One upshot of this is that resource-poor autocracies are more likely to transition to democracy. (Although, it should be noted that some scholars have disputed the claim that petroleum wealth reinforces autocratic rule; see, for example, Haber and Menaldo, 2011; Wacziarg, 2012). For similar reasons it is argued that access to oil revenues enhances the ability of incumbent elected leaders to secure re-election (Goldberg et al., 2008; Mahdavi, 2015). Thus, access to non-tax revenues enhance the ability of autocratic and democratic leaders to stay in power. In both cases the government can provide benefits to its supporters without incurring the political cost of imposing taxes.

What this also means is that the survival of autocratic and democratic leaders in resource-poor countries is dependent on their ability to provide benefits to supporters whilst avoiding the political cost of taxation (Bueno de Mesquita and Smith, 2010). That in turn is dependent on economic growth. Increasing government revenue by raising new taxes is more unpopular than relying on a combination of economic growth and unchanged or lower tax rates to increase the tax yield. Thus, governments in resource-poor countries have a greater incentive to invest in public goods such as health and education that are key determinants of labor productivity and, therefore, economic growth (Lindert, 2004). Child health is a crucial determinant of education outcomes and, therefore, labor productivity. That is because disease-free children are more likely to attend school and to learn more while they are there (Baird et al., forthcoming; Bleakley, 2007). In addition, parents have an increasing incentive to send their children to school as survival rates improve (Soares, 2005). Childhood health may also have a more direct impact on labor productivity. Maladies that are endured during childhood may continue to incapacitate individuals as they reach working age (Bleakley, 2010). Thus, the survival of political leaders in resource-poor countries is indirectly linked to their ability to improve the health of the youngest members of society. Indeed, the provisioning of schooling and health care is optimal for the political leader who lacks access to non-tax revenues. Public goods that improve child health and education appease the government's backers and generate the economic growth that reduces the need for higher tax rates to finance those public goods. By contrast political leaders in resource-rich countries can rely on a source of revenue that is not dependent on how much they invest in child health and education. As a result, their political survival is less likely to be threatened by a failure to reduce child mortality. That is to say, they are less likely to be voted out of office (in the case of democratic leaders) or removed by revolution or coup (in the case of autocratic leaders).

We predict, therefore, that countries that have significant oil revenues will be less successful at reducing child mortality than countries without significant oil revenues. While the former may have more resources to improve child health they also have less of an incentive to do so. This prediction is broadly in keeping with existing research which finds that resource rich countries typically underinvest in productive capital, such as health and education, even though it is a key determinant of economic growth (Hamilton et al., 2006; van der Ploeg, 2011). That finding is reinforced by another study that found that petroleum wealth is negatively associated with public spending on health (Cockx and Francken, 2014). However, it should be noted that the impact of public spending on mortality and morbidity is significantly dependent on the targeting of health-promoting resources, rather than simply the magnitude of those resources (Filmer and Pritchett, 1999). More explicit support for our hypothesis is provided by a study of 137 countries for the years 1990-2008 which found that petroleum wealth is associated with a reduced capacity to prevent the spread of HIV/AIDS (de Soysa and Gizelis, 2013).

\section{Model, variables and data}

In order to test the claim that oil wealth leads to higher levels of child mortality we employ a panel of 167 countries for each year from 1960 to 2011 to analyze the relationship between oil wealth and child mortality. The estimation model takes the following form.

$$
\begin{aligned}
\ln (\text { Under5 mortality })_{i t+1}= & \beta_{0}+\beta_{1} \ln (\text { Oil Income })_{i t}+\beta_{2} \ln (\mathrm{X})_{i t} \\
& +u_{i t+1}
\end{aligned}
$$

Where $i$ is the country, $t$ is the year and $X$ is the set of control variables. We include country fixed-effects in order to control for those unchanging or slow-changing factors, such as culture and inveterately weak state capacity, which may be independently determining oil wealth and child health. In effect this means we are comparing each country with itself over time in order to see whether increases in the level of oil wealth is associated with higher levels of child mortality. In addition, we include year dummies so as to control for the possibility of a spurious correlation between the political variables and child mortality. That is necessary given that there was a downward trend in child mortality around the world in recent decades (Hill et al., 2012). Finally, we lag all the independent variables by one year so as to reduce endogeneity.

\subsection{Dependent variable}

Our measure of child health is the probability, per 1000 live births, that a newborn baby will die before reaching the age of five (Under-5 mortality). The mortality data is taken from the UN InterAgency Group for Child Mortality Estimation (IGME, 2016). We prefer under-5 mortality over infant mortality because the latter is more susceptible to undercounting, especially in poor countries (Anthopolos and Becker, 2010). We assume that it becomes increasingly difficult to achieve a marginal decrease in under-5 mortality as its level is lowered. Thus, in the empirical analysis that follows we take the natural log transformation of the dependent variable.

\subsection{Independent variables}

Our measure of natural resource wealth is the natural log (plus 
one) of total oil income per capita (in 2000 constant dollars) and is taken from the data set constructed by Ross and Mahdavi (2015). That variable is calculated by deducting extraction costs from the total value of a country's oil and natural gas production. This represents a more accurate measure of oil rents than oil exports divided by GDP because it also captures oil and gas that is produced and consumed domestically. In addition, it does not indirectly measure the size of a country's economy or inflate the magnitude of oil rents in poorer countries (Ross, 2012, pp. 15-16). In the latter case this may produce a spurious correlation because oil export dependence may lead to higher child mortality rates or both may be separately produced by the level of poverty in a country.

The fixed-effect specification that we use helps to mitigate any omitted variable bias. Nevertheless, it is necessary to control for those time-varying factors that might be simultaneously determining the level of oil wealth (e.g. extraction rates) as well as the level of under- 5 mortality. For that reason we include the natural log of income (real gross domestic product per capita, in constant 2005 dollars; Heston et al., 2012), urbanization (share of population living in urban areas; World Bank, 2016), and trade openness (total trade as a proportion of gross domestic product; Heston et al., 2012) to control for economic wealth, economic development, and exposure to international competition.

We focus on petroleum wealth in this study because it dominates the global market for natural resources. Petroleum by itself accounts for approximately $90 \%$ of the global trade in minerals. In addition, the cost of extracting oil is often significantly lower than its market value and it can be taxed more easily than other minerals (Barma et al., 2011, pp. 14-15, 18). We expect, therefore, that it will have a decisive impact on government policy in oil-producing countries. A further reason for focusing on petroleum wealth is that it is markedly easier to obtain reliable data on oil and gas reserves and production than is the case for other mineral resources such as diamonds.

Some have argued that the incentive to discover more oil and extract existing reserves may be higher in countries that are autocratic, undergoing civil war, or subject to high levels of poverty (Menaldo, 2016, pp. 66-70; Wacziarg, 2012). If correct this may lead to spurious correlations because all three factors are also associated with higher mortality rates among children (see, for example, Gerring et al., 2012; Ghobarah et al., 2003). Michael Ross argues that exploration and extraction rates are actually likely to be lower in countries that are undemocratic, conflict ridden and impoverished because they represent an investment risk for extractive firms (Ross, 2015, p. 243, 2012, pp. 17-22). Nevertheless, we take steps to control for the possibility that those factors independently increase oil income and child mortality.

To control for level of democracy we include the polity2 index that has been constructed by the Polity IV Project (Marshall and Jaggers, 2016). The polity2 index is based on the extent to which political participation is competitive, the openness and competitiveness of executive recruitment, and the extent to which the chief executive is subject to institutional constraints. Those three components are converted into a 21-point scale for each year, with the most autocratic countries receiving a score of -10 (e.g. Saudi Arabia) and the most democratic countries receiving a score of +10 (e.g. Norway).

To control for the impact of conflict, we include two dummy variables indicating whether a country is undergoing a civil conflict (internal war) or an internationalized conflict (external war). These two variables were constructed based on the UCDP/PRIO Armed Conflict Dataset (UCDP/PRIO, 2015).

Our control for poverty is based on the mean daily calorie intake (in kilocalories) data that is compiled in standardized form by the Food and Agricultural Organization (FAO, 2014). The biological limit on how much a person can consume and the difficulty of hoarding food means that increases in mean calorie intake will typically reflect an improvement in the nutritional levels of the poor (Blaydes and Kayser, 2011). We convert that raw data into a poverty measure by subtracting the value for each country-year from the maximum value in the data set. We prefer this measure of poverty over more familiar measures such as income poverty because the data is available for most countries in the world as far back as 1961 and is comparable across time and place. The natural log (plus one) of this indicator of poverty, which we label as calorie shortfall, is employed so as to render the distribution of values less skewed.

\subsection{Data set}

After constructing the data set we found that observations were missing for a small proportion of country-years (see online appendix, Table A.2.1). Deleting those cases with missing values may deprive the model of relevant information. In addition, it may bias the results if there is a systematic difference between the observed and unobserved data. It may be the case, for example, that oil rich states perform well in terms of improving child health and yet are less likely to report health and economic data to international agencies. This is possible because those states are typically not dependent on foreign aid and so are less likely to heed international pressure to collect and report development data. At least two studies have found that development data is more likely to be missing for autocratic states (Hollyer et al., 2011; Ross, 2006). This is relevant to the present study because of the evidence that suggests that oil rents bolster autocratic regimes and prevent democratic transitions. Thus, rather than applying the method of listwise deletion, we use the Amelia multiple imputation algorithm to estimate the missing values (Honaker et al., 2013). Using the multiple imputation process meant we were able to generate a balanced panel for the 167 countries that were extant in the world from 1961 to 2011 and had populations greater than 250,000. In order to ensure the robustness of our findings we also ran the baseline model using the original, non-imputed, data set. Detailed variable descriptions, descriptive statistics as well as a complete description of the multiple imputation process can be found in the online appendix.

\section{Results}

The results of our analysis are presented in Table 1 . In column 1 we examine the relationship between oil rents and child health, in the absence of any time-varying control variables. As we can see our measure of oil rents (oil income) is positively associated with under-5 mortality, but is not statistically significant. (It should be noted, however, that oil income for the bivariate analysis carries the expected sign and obtains statistically significance when we use instrumental variables to mitigate the possibility of endogeniety; see column 6 and below).

As we can see from column 2 the coefficient for oil income is statistically significant and carries the expected sign when controls are introduced for wealth, economic development and trade openness. In columns 3 and 4 we control for the possibility that oil wealth and under-5 mortality are independently determined by the level of democracy (polity2), conflict (internal war and external war) and poverty (calorie shortfall). In all three cases we find that oil income remains positively associated with under-5 mortality.

The inclusion of the various time-varying controls is necessary in order to counter the possibility of omitted variable bias. However, GDP per capita includes oil income, and so its inclusion may eliminate the potentially salutary effect of petroleum wealth. For example, increases in oil income may lead to an improvement in 
Table 1

Oil wealth and Under-5 mortality.

\begin{tabular}{|c|c|c|c|c|c|c|c|c|c|c|c|}
\hline & (1) & $(2)$ & (3) & (4) & (5) & (6) & (7) & (8) & (9) & (10) & (11) \\
\hline Oil income (ln) & $\begin{array}{l}0.0069 \\
(0.0078)\end{array}$ & $\begin{array}{l}0.0324^{* * *} \\
(0.0084)\end{array}$ & $\begin{array}{l}0.0307^{* * *} \\
(0.0082)\end{array}$ & $\begin{array}{l}0.0227^{* * *} \\
(0.0069)\end{array}$ & $\begin{array}{l}0.0231^{* * *} \\
(0.0087)\end{array}$ & $\begin{array}{l}0.0191^{*} \\
(0.0001)\end{array}$ & $\begin{array}{l}0.0455^{* * *} \\
(0.0001)\end{array}$ & $\begin{array}{l}0.0287^{* * *} \\
(0.0076)\end{array}$ & & $\begin{array}{l}0.0255^{* * *} \\
(0.0072)\end{array}$ & $\begin{array}{l}0.0372^{* * *} \\
(0.0108)\end{array}$ \\
\hline Tax reliance $(\ln )$ & & & & & & & & & $\begin{array}{l}-0.2224^{* * *} \\
(0.0831)\end{array}$ & & \\
\hline Polity2 & & & $\begin{array}{l}-0.0056^{* *} \\
(0.0025)\end{array}$ & $\begin{array}{l}-0.0079^{* * *} \\
(0.0025)\end{array}$ & $\begin{array}{l}-0.0073^{* *} \\
(0.003)\end{array}$ & & $\begin{array}{l}-0.0044^{* * *} \\
(0.0008)\end{array}$ & $\begin{array}{l}-0.0054^{* *} \\
(0.0024)\end{array}$ & $\begin{array}{l}-0.0005 \\
(0.0022)\end{array}$ & $\begin{array}{l}-0.0031^{* *} \\
(0.0023)\end{array}$ & $\begin{array}{l}-0.0041 \\
(0.0026)\end{array}$ \\
\hline Internal war & & & $\begin{array}{l}0.0023 \\
(0.0217)\end{array}$ & $\begin{array}{l}-0.0088 \\
(0.0199)\end{array}$ & $\begin{array}{l}0.0098 \\
(0.0261)\end{array}$ & & $\begin{array}{l}0.0195^{*} \\
(0.0094)\end{array}$ & $\begin{array}{l}0.0025 \\
(0.0215)\end{array}$ & $\begin{array}{l}-0.0025 \\
(0.0175)\end{array}$ & $\begin{array}{l}-0.0115 \\
(0.0192)\end{array}$ & $\begin{array}{l}0.0051 \\
(0.0207)\end{array}$ \\
\hline External war & & & $\begin{array}{l}0.0426 \\
(0.0482)\end{array}$ & $\begin{array}{l}0.0675 \\
(0.0433)\end{array}$ & $\begin{array}{l}-0.005 \\
(0.0685)\end{array}$ & & $\begin{array}{l}0.047^{*} \\
(0.0174)\end{array}$ & $\begin{array}{l}0.0539 \\
(0.0464)\end{array}$ & $\begin{array}{l}-0.002 \\
(0.0305)\end{array}$ & $\begin{array}{l}0.0487 \\
(0.0476)\end{array}$ & $\begin{array}{l}0.0799 \\
(0.0435)\end{array}$ \\
\hline Calorie shortfall $(\ln )$ & & & & $\begin{array}{l}0.181^{* * *} \\
(0.0518)\end{array}$ & & & & & & & \\
\hline Income (ln) & & $\begin{array}{l}-0.3902^{* * *} \\
(0.0336)\end{array}$ & $\begin{array}{l}-0.3931^{* * *} \\
(0.0332)\end{array}$ & $\begin{array}{l}-0.3552^{* * *} \\
(0.0339)\end{array}$ & $\begin{array}{l}-0.3527^{* * *} \\
(0.0437)\end{array}$ & & $\begin{array}{l}-0.4017^{* * *} \\
(0.0001)\end{array}$ & $\begin{array}{l}-0.3859^{* * *} \\
(0.0336)\end{array}$ & $\begin{array}{l}-0.1665^{* * *} \\
(0.0386)\end{array}$ & $\begin{array}{l}-0.3566^{* * *} \\
(0.0303)\end{array}$ & $\begin{array}{l}-0.356^{* * *} \\
(0.0511)\end{array}$ \\
\hline Urbanization (ln) & & $\begin{array}{l}0.276^{* * *} \\
(0.0704)\end{array}$ & $\begin{array}{l}0.2761^{* * *} \\
(0.0702)\end{array}$ & $\begin{array}{l}0.274^{* * *} \\
(0.0681)\end{array}$ & $\begin{array}{l}0.2844^{* * * *} \\
(0.0801)\end{array}$ & & $\begin{array}{l}0.331^{* * *} \\
(0.0204)\end{array}$ & $\begin{array}{l}0.254^{* * *} \\
(0.0644)\end{array}$ & $\begin{array}{l}0.2074^{* *} \\
(0.1042)\end{array}$ & $\begin{array}{l}0.2889 * * * \\
(0.0628)\end{array}$ & $\begin{array}{l}0.3553^{* * *} \\
(0.073)\end{array}$ \\
\hline Trade openness (ln) & & $\begin{array}{l}-0.0638^{* * *} \\
(0.0231)\end{array}$ & $\begin{array}{l}-0.0583^{* * *} \\
(0.0231)\end{array}$ & $\begin{array}{l}-0.0635^{* * *} \\
(0.022)\end{array}$ & $\begin{array}{l}-0.0497 \\
(0.0368)\end{array}$ & & $\begin{array}{l}-0.0566^{* * *} \\
(0.0087)\end{array}$ & $\begin{array}{l}-0.0513^{* *} \\
(0.0215)\end{array}$ & $\begin{array}{l}-0.0396 \\
(0.0275)\end{array}$ & $\begin{array}{l}-0.0642^{* * *} \\
(0.0207)\end{array}$ & $\begin{array}{l}-0.0663^{*} \\
(0.0378)\end{array}$ \\
\hline Ethnic fractionalization & & & & & & & & $\begin{array}{l}-0.0528 \\
(0.1325)\end{array}$ & & & \\
\hline Landlocked & & & & & & & & $\begin{array}{l}0.2548^{* * *} \\
(0.0689)\end{array}$ & & & \\
\hline Temperate & & & & & & & & $\begin{array}{l}-0.5301^{* * *} \\
(0.1075)\end{array}$ & & & \\
\hline Muslim & & & & & & & & $\begin{array}{l}0.0033^{* * *} \\
(0.001)\end{array}$ & & & \\
\hline Catholic & & & & & & & & $\begin{array}{l}-0.001 \\
(0.0009)\end{array}$ & & & \\
\hline Year dummies & $\checkmark$ & $\checkmark$ & $\checkmark$ & $\checkmark$ & $\checkmark$ & $\checkmark$ & $\checkmark$ & $\checkmark$ & $\checkmark$ & $\checkmark$ & $\checkmark$ \\
\hline Country fixed-effects & $\checkmark$ & $\checkmark$ & $\checkmark$ & $\checkmark$ & $\checkmark$ & $\checkmark$ & $\checkmark$ & & $\checkmark$ & $\checkmark$ & $\checkmark$ \\
\hline Multiple imputation & $\checkmark$ & $\checkmark$ & $\checkmark$ & $\checkmark$ & $\checkmark$ & $\checkmark$ & $\checkmark$ & $\checkmark$ & $\checkmark$ & $\checkmark$ & \\
\hline $\begin{array}{l}\text { World region dummies } \\
\text { Legal origin dummies }\end{array}$ & & & & & & & & $\checkmark$ & & & \\
\hline Countries & 167 & 167 & 167 & 156 & 167 & 167 & 167 & 167 & 164 & 167 & 165 \\
\hline Years & $\begin{array}{l}1961 \\
-2011\end{array}$ & $\begin{array}{l}1961 \\
-2011\end{array}$ & $\begin{array}{l}1961 \\
-2011\end{array}$ & $\begin{array}{l}1962 \\
-2011\end{array}$ & $\begin{array}{l}1965 \\
-2010\end{array}$ & $\begin{array}{l}1961 \\
-2004\end{array}$ & $\begin{array}{l}1961 \\
-2004\end{array}$ & $\begin{array}{l}1961 \\
-2011\end{array}$ & $\begin{array}{l}1981 \\
-2011\end{array}$ & $\begin{array}{l}1961 \\
-2011\end{array}$ & $\begin{array}{l}1961 \\
-2011\end{array}$ \\
\hline Observations & 8517 & 8517 & 8517 & 7800 & 1670 & 7348 & 7348 & 8517 & 5084 & 8517 & 6791 \\
\hline $\begin{array}{l}\text { Hansen J statistic } \\
\text { Kleibergen-Paap rk Wald F }\end{array}$ & & & & & & $\begin{array}{l}0.49 \\
186.72\end{array}$ & $\begin{array}{l}0.35 \\
152.48\end{array}$ & & & & \\
\hline
\end{tabular}

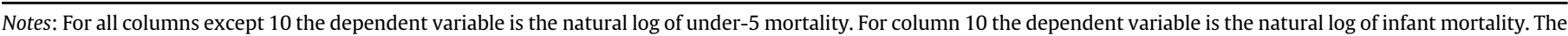

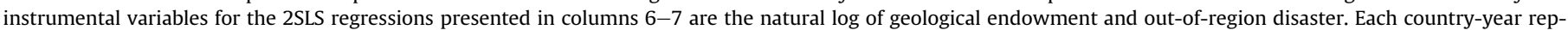

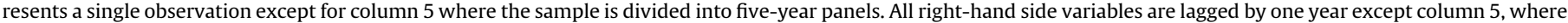
they are lagged by five years. Robust standard clustered at country level errors are reported in parenthesis. ${ }^{* * *}$ significant at $1 \%$; ${ }^{* *} 5 \%$; * $10 \%$.

household incomes and, thereby, child health. Whether that is the case will largely depend on the extent to which oil wealth boosts the income of the poorest households, where child ill-health is more prevalent. Nevertheless, the coefficient for oil income in the specifications that include GDP per capita should be interpreted with caution. The coefficient for that variable when we set aside the time-varying controls (Table 1 , columns $1 \& 6$ ) represents the overall average effect of oil income on under-5 mortality. As we have already noted it carries the expected sign, but only achieves statistical significance when oil income is instrumented (column 6). Thus, we have at best weak evidence that the deleterious effect of oil income outweighs the potentially beneficial effect of oil income.

The most we can say, therefore, is that our evidence is consistent with the claim that there is a causal channel through which petroleum wealth has a harmful effect on child health (captured by the coefficient for oil income in the specifications that include GDP per capita). It remains possible that that harmful effect is at least partially offset by the potentially salutary effect of petroleum wealth via another causal channel that is obscured by one or more of the time-varying controls. This leads us to the more modest claim that resource-rich countries do not perform as well as they should, given the windfall at their disposal. All other things being equal, the same income increase in a resource-poor country is more likely to be re-invested by the government in health care and education. In other words, resource-poor countries will typically outperform resource-rich countries with respect to child health because human capital formation remains more of a priority. Thus, the results are in keeping with our hypothetical claim that governments in countries with an abundant supply of oil and gas have less of an incentive to reduce child mortality.

\section{Robustness checks}

In order to ensure the robustness of our findings we examined whether our baseline results held after various adjustments were made to the model specification and the way in which we measured oil rents and child health.

We have endeavored to counter the possibility of endogeniety between oil income and under- 5 mortality by lagging the righthand side variables by one year behind the outcome in the 
baseline regressions. This provides some assurance against the possibility of circularity between the dependent and independent variables and the potential presence of an unmeasured (timevarying) factor that is simultaneously determining the dependent and independent variables. In column 5 we take this approach a step further by dividing the sample into five year panels between 1965 and 2010 and lagging the right-hand side variables by five years. This also allows us to examine whether oil income continues to have a negative impact on child mortality over time. As we can see the estimated coefficient for oil income retains the expected sign and remains statistically significant.

In order to further address the possibility of endogeniety bias we employed two instrumental variables for oil income. The first instrument is the (natural log plus one of) cumulative total oil barrels (in million barrels of oil equivalent) associated with giant oil and gas fields in each country. Giant oil or gas fields contain at least 500 million barrels of oil equivalent that can ultimately be recovered. Discovering such fields is significantly easier than discovering smaller fields, which require substantial exploratory efforts. Thus, this represents the most exogenous (time-varying) measure of geological endowment (Menaldo, 2016, pp. 280-281). Our data source for this variable is Horn (2015). The second instrument uses (the natural log of) out-of-region natural disasters to proxy for price increases. The underlying assumption for this variable is that a disaster affecting an oil-producing country will increase oil prices and, thereby, the oil income of unaffected oil-producers. This instrument was originally proposed and utilized by Ramsay (2011) to examine the political resource curse. Unlike Ramsay, however, we retain country fixed-effects so as to control for the ability of large oil-producers to increase production in response to unexpected interruptions to the supply of oil (Menaldo, 2016, pp. 63-64). Our data source for this variable is Cotet and Tsui (2013b).

We estimate a 2SLS regression with country and year fixed effects, as well as robust standard errors. Both instruments, as well as the control variables, enter the first stage of the regression as predictors of oil income. The second stage regression estimates the coefficient for oil income based on the first stage regression. As we can see from columns 6 and 7 the second stage regression produces results that are consistent with the bivariate (column 1) and baseline regressions (column 3) (we do not report the first stage regression for reasons of space). In addition, the Kleibergen-Paap Wald F-stat and Hansen p-values indicate, respectively, that the instruments are sufficiently correlated with the potentially endogenous regressor (oil income) and that they are not directly correlated with the dependent variable (under-5 mortality) (i.e. the exclusion restriction is met). This suggests they are strong and valid instruments for the independent variable of interest.

Fixed-effect specifications are crucial as they provide a way to control for unchanging or slow changing factors (social norms, geography, colonial history, etc.) that may be determining the dependent variable and the main independent variables of interest, thereby producing spurious correlations. However, that type of specification tends to underestimate the significance of variables that are slow changing over time. We therefore re-ran the baseline model without country fixed-effects, but with a range of controls for unchanging factors that may confound the results. Those timeinvariant controls are ethnic fractionalization (probability that two randomly chosen individuals from the same population belong to the same ethnic group; Alesina et al., 2003), landlocked (dummy variable indicating whether a country has direct access to an open sea), temperate (the proportion of the population living in a temperate climate zone; Gallup et al., 2010), world region (dummy variable based on the World Bank's classification, East Asia \& Pacific, Europe \& Central Asia, Latin America \& Caribbean, SubSaharan Africa, Western), legal origin (dummy variable indicating the origin of each country's legal system, British, Socialist/ Communist, French, German, Scandinavian; La Porta et al., 1999), Muslim and catholic (percentage of the population that belong to either of those belief systems; La Porta et al., 1999). As we can see from column 8 the results are similar to those obtained for the fixed-effects specification.

In column 9 we examine whether our results hold for an alternative indicator of oil wealth. One potential shortcoming of our default measure of oil wealth is that it covers all income from oil and gas production and, therefore, includes income that is accrued by privately owned companies. Thus, oil income may overstate the revenue that each government obtains from natural resources. A more precise measure of government revenue from natural resources has recently been compiled by the International Center for Taxation and Development (ICTD) (Prichard et al., 2014a). Based on that data set we construct a variable that indicates the degree to which a government's revenue is not dependent on natural resources. Tax reliance is the government's revenue secured through non-resource taxation as a share of GDP divided by total government revenue as a share of GDP (Prichard et al., 2014b). We have argued that governments that obtain much of their revenue from natural resources have less of an incentive to improve the health of children than those governments that obtain much of their revenue from taxing economically productive activity. We expect, therefore, that those countries that are more dependent on non-resource taxation will be more successful at reducing child mortality. As we can see from column 6 the natural log (plus one) of tax reliance is, as predicted, negatively associated with under-5 mortality. Nevertheless, we prefer to use oil income as our primary indicator of oil wealth because data for that variable is available for more countries and for a longer period of time (50 years as opposed to 30 years). In addition, a smaller proportion of the data for that variable is missing (see online appendix Table A.2).

In column 10 we replace the dependent variable with an alternative measure of child health. Infant mortality is the probability, per 1000 live births, that a newborn baby will die before reaching the age of one (IGME, 2016). Reassuringly the results are consistent with those that we obtained for under-5 mortality.

Finally we examined whether our baseline results held when the models were estimated based on the non-imputed data set. Reassuringly, the results are very similar the baseline estimations suggesting that our findings are not simply an artifact of the imputation model (see column 11). However, we prefer to rely on the estimations that are based on the data sets that are produced by multiple imputation because that allows us to include more information and to avoid the possibility of selection bias (e.g. the listwise deletion of oil-rich states that perform well with respect to mortality-reduction or oil-poor states that perform badly with respect to mortality-reduction).

Further robustness checks are reported in the online appendix (Table A.3). In the appendix we firstly examine whether our results held when oil income was replaced by three indicators of natural resource rents that have been constructed by Haber and Menaldo (2011) up to 2006. Those indicators are total oil income per capita (total value of petroleum produced, in 2007 dollars), total fuel income per capita (total value of petroleum, coal and natural gas produced, in 2007 dollars) and total resources income per capita (total value of petroleum, coal, natural gas and metals produced, in 2007 dollars). The first indicator is similar to the measure of oil wealth that we have used in the baseline regressions, although it does not take into account extraction costs. The latter two indicators include additional sources of natural wealth, namely coal and metals. Reassuringly our results held when we employed those alternative measures of resource wealth (Table A.3, columns 1-3). Column 4 of Table A.3 addresses the possibility that the right and 
left hand variables of interest might lead to spurious results if they are both highly trended. In order to control for that possibility we included the lag of the dependent variable on the right-hand side. Reassuringly this method for de-trending the data did not produce results that are inconsistent with our baseline estimations. Finally, it may be argued that our control for regime-type, polity2, is inadequate because it does not take into account the proportion of the population that is permitted to participate in the selection of public officials (Munck and Verkuilen, 2002, p. 11). In order to address that concern we weight the extent of electoral participation based on the polity2 score. The inclusion of the revised version of polity 2 produces results that are qualitatively similar to the baseline regressions (Table A.3, column 5).

\section{Discussion and concluding remarks}

Scholars have long noted that the physical geography of the earth's surface can have a significant impact on population health, whether directly through factors that affect disease vectors such as climatic conditions, or indirectly through factors that influence the economy such as soil quality and access to an open sea. In this study we have argued that oil and gas deposits below the earth's surface can have an impact on population health, in virtue of their influence on government policy priorities. Paradoxically it seems that those countries that have been gifted the resources to improve child health are less successful at preventing child mortality.

This finding is significant given the ever-growing demand for oil, which has resulted in an increase in the number of countries that have become oil providers in recent years. Most of those new oilproducing countries are poor, the very countries where child mortality is already pronounced (Klare and Volman, 2006; Ross, 2012, pp. 26 \& 30). Chad is a case in point. Oil exports from this landlocked and poor country began in 2004. The World Bank was heavily involved in the process as early as 2000 , with the hope that the oil windfall would be used to alleviate poverty. Despite the efforts of international agencies infant and child mortality in Chad actually increased slightly after 2004. Government spending on health also increased during this time, suggesting that healthpromoting resources did not reach those that needed them the most (Frank and Guesnet, 2009, pp. 47-48). The case of Equatorial Guinea further illustrates the problem. The discovery of large oil reserves during the 1990s, followed by rising oil prices during the first decade of the new century, propelled average income in that country to a higher level than Japan, Germany and France by 2010. Nevertheless, it remains the case that three-quarters of the population live below the poverty line and half the population does not have access to clean drinking water or adequate sanitation (Wenar, 2016, p. 69).

This version of the resource curse appears to afflict most of the 14 Sub-Saharan countries that increased their oil revenues during the first decade of the new millennium. 11 of those countries reduced child mortality less than the average for the region as a whole and less than the average for those countries around the world that are in the same income group (those Sub-Saharan countries that increased their oil income between 2000 and 2010 are Angola, Cameroon, Chad, Democratic Republic of Congo, Equatorial Guinea, Gabon, Ghana, Ivory Coast, Mauritania, Nigeria, Sudan, Republic of Congo, Tanzania and Mozambique. Only the latter three performed better than the average for the region and their income group. See Fig. 1 in the online appendix. The income group for each country was determined based on the World Bank's classification - low income, lower middle-income, upper middleincome and high income. As before we used the natural log of under-5 mortality to calculate the drop in mortality given the expectation that it is harder to achieve a reduction at lower initial rates). This is consistent with the findings of a recent poverty report on Sub-Saharan Africa. The authors of that report found that, for the period 2000-2012, healthy life expectancy (the number of years that a newborn can expect to live in full health) was on average 4.5 years shorter in resource-rich countries in the region than other countries in the region (Beegle et al., 2016, pp. 90-91).

The adverse effect of oil abundance on government spending priorities represents a significant challenge for development policy. It is difficult to see what might motivate the leaders of oil-rich states to further invest in child health, given that their political survival does not typically depend on the formation of human capital. However, it should be pointed out that some oil-rich countries have been able to reduce child mortality to a greater extent than the average for their income group. It is noteworthy, for example, that some countries in the Middle East, such as Saudi Arabia, Oman, Bahrain and Qatar, that have been afflicted by the political resource curse (i.e. entrenched autocratic rule), have managed to achieve substantial improvements in child health. Similarly, some oil-rich democracies, such as Norway, Brazil and Mexico, have also been able to perform significantly better than the average for those countries in the same income group. In the online appendix (section 4) we examine whether the quality of government institutions might explain why some countries have managed to avoid the negative impact of oil wealth on child health. However, those results are at best suggestive. Further research is needed in order to ascertain those background factors and development policies that might prevent the health resource curse.

\section{Appendix A. Supplementary data}

Supplementary data related to this article can be found at http:// dx.doi.org/10.1016/j.socscimed.2017.01.038.

\section{References}

Alesina, A., Devleeschauwer, A., Easterly, W., Kurlat, S., Wacziarg, R., 2003. Fractionalization. J. Econ. Growth 8, 155-194. http://dx.doi.org/10.1023/A: 1024471506938

Anthopolos, R., Becker, C.M., 2010. Global infant mortality: correcting for undercounting. World Dev. 38, 467-481. http://dx.doi.org/10.1016/ j.worlddev.2009.11.013.

Baird, S., Hicks, J.H., Kremer, M., Miguel, E., forthcoming. Worms at Work: Long-run Impacts of a Child Health Investment. The Quarterly Journal of Economics. http://dx.doi.org/10.1093/qje/qjw022.

World Bank, 2016. World Development Indicators 2016 [WWW Document]. http:// data.worldbank.org/data-catalog/world-development-indicators.

Barma, N., Kaiser, K., Le, T.M., Viñuela, L., 2011. Rents to Riches?: the Political Economy of Natural Resource-led Development. World Bank Publications.

Beegle, K., Christiaensen, L., Dabalen, A., Gaddis, I., 2016. Poverty in a Rising Africa. The World Bank, Washington D.C.

Blaydes, L., Kayser, M.A., 2011. Counting calories: democracy and distribution in the developing world. Int. Stud. Q. 55, 887-908. http://dx.doi.org/10.1111/j.14682478.2011.00692.x.

Bleakley, H., 2007. Disease and development: evidence from Hookworm eradication in the american south. Q. J. Econ. 122, 73-117. http://dx.doi.org/10.1162/ qjec.121.1.73.

Bleakley, H., 2010. Health, human capital, and development. Annu. Rev. Econ. 2 , 283-310. http://dx.doi.org/10.1146/annurev.economics.102308.124436.

Bueno de Mesquita, B., Smith, A., 2010. Leader survival, revolutions, and the nature of government finance. Am. J. Political Sci. 54, 936-950. http://dx.doi.org/ 10.1111/j.1540-5907.2010.00463.x.

Cockx, L., Francken, N., 2014. Extending the concept of the resource curse: natural resources and public spending on health. Ecol. Econ. 108, 136-149. http:// dx.doi.org/10.1016/j.ecolecon.2014.10.013.

Cotet, A.M., Tsui, K.K., 2013a. Oil, growth, and health: what does the cross-country evidence really Show?: oil, growth, and health. Scand. J. Econ. 115, 1107-1137. http://dx.doi.org/10.1111/sjoe.12027.

Cotet, A.M., Tsui, K.K., 2013b. Oil and conflict: what does the cross country evidence really show? Am. Econ. J. Macroecon. 5, 49-80. http://dx.doi.org/10.1257/ mac.5.1.49.

de Looper, M., Lafortune, G., 2009. Measuring Disparities in Health Status and in Access and Use of Health Care in OECD Countries (Working Paper No. 43), OECD Health Working Papers. Organisation for Economic Co-operation and Development, Paris. 
de Soysa, I., Gizelis, T.-I., 2013. The natural resource curse and the spread of HIV/ AIDS, 1990-2008. Soc. Sci. Med. 77, 90-96. http://dx.doi.org/10.1016 j.socscimed.2012.11.010

Filmer, D., Pritchett, L., 1999. The impact of public spending on health: does money matter? Soc. Sci. Med. 49, 1309-1323.

Food and Agricultural Organization (FAO), 2014. Food Balance Sheets [WWW Document]. FAOSTAT. http://faostat3.fao.org/download/FB/*/E (accessed 24 August 2016).

Frank, C., Guesnet, L., 2009. "We Were Promised Development and All We Got Is Misery" - the Influence of Petroleum on Conflict Dynamics in Chad. (Brief No. 41). Bonn International Center for Conversion, Bonn.

Gallup, J.L., Mellinger, A.D., Sachs, J.D., 2010. Geography Datasets [WWW Document]. Center for International Development Dataverse. http://hdl.handle.net/ 1902.1/14429 (accessed 24 May 2016).

Gerring, J., Thacker, S.C., Alfaro, R., 2012. Democracy and human development. J. Polit. 74, 1-17. http://dx.doi.org/10.1017/S0022381611001113.

Ghobarah, H.A., Huth, P., Russett, B., 2003. Civil wars kill and maim people-long after the shooting stops. Am. Political Sci. Rev. 97, 189-202. http://dx.doi.org/ 10.1017/S0003055403000613.

Goldberg, E., Wibbels, E., Mvukiyehe, E., 2008. Lessons from strange cases democracy: development, and the resource curse in the U.S. States. Comp. Polit. Stud. 41, 477-514. http://dx.doi.org/10.1177/0010414007313123.

Haber, S., Menaldo, V., 2011. Do natural resources fuel Authoritarianism? A reappraisal of the resource curse. Am. Political Sci. Rev. 105, 1-26. http://dx.doi.org/ 10.1017/S0003055410000584.

Hamilton, K., Ruta, G., Tajibaeva, L., 2006. Capital accumulation and resource depletion: a Hartwick rule counterfactual. Environ. Resour. Econ. 34, 517-533. http://dx.doi.org/10.1007/s10640-006-0011-2.

Heston, A., Summers, R., Aten, B., 2012. Penn World Table 7.1,Center for International Comparisons of Production [WWW Document]. Income and Prices at the University of Pennsylvania. http://www.rug.nl/research/ggdc/data/pwt/pwt-7.1 (accessed 20 December 2015).

Hill, K., You, D., Inoue, M., Oestergaard, M.Z., 2012. Child mortality estimation: accelerated progress in reducing global child mortality. PLoS Med. 9, 1-11.

Hollyer, J.R., Rosendorff, B.P., Vreeland, J.R., 2011. Democracy and transparency. J. Polit. 73, 1191-1205. http://dx.doi.org/10.1017/S0022381611000880.

Honaker, J., King, G., Blackwell, M., 2013. Amelia II: a Program for Missing Data [WWW Document]. http://gking.harvard.edu/amelia/.

Horn, M.K., 2015. Giant, Supergiant \& Megagiant Oil and Gas Fields of the World [WWW Document]. https://edx.netl.doe.gov/dataset/aapg-datapages-giant-oiland-gas-fields-of-the-world (accessed 5 January 2017).

Klare, M., Volman, D., 2006. America, China \& the scramble for Africa's oil. Rev. Afr: Political Econ. 33, 297-309.

La Porta, R., Lopez-de-Silanes, F., Shleifer, A., Vishny, R., 1999. The quality of government. JLEO 15, 222-279. http://dx.doi.org/10.1093/jleo/15.1.222.

Levi, M., 1989. Of Rule and Revenue. University of California Press.

Lindert, P.H., 2004. Growing Public: Volume 1 Social Spending and Economic Growth since the Eighteenth Century. Cambridge University Press, Cambridge.

Liu, L., Oza, S., Hogan, D., Perin, J., Rudan, I., Lawn, J.E., Cousens, S., Mathers, C.,
Black, R.E., 2015. Global, regional, and national causes of child mortality in 2000-13, with projections to inform post-2015 priorities: an updated systematic analysis. Lancet 385, 430-440. http://dx.doi.org/10.1016/S01406736(14)61698-6.

Mahdavi, P., 2015. Explaining the oil advantage: effects of natural resource wealth on incumbent reelection in Iran. World Polit. 67, 226-267. http://dx.doi.org/ $10.1017 /$ S0043887114000392.

Mahdavy, H., 1970. The patterns and problems of economic development in rentier states: the case of Iran. In: Cook, M.A. (Ed.), Studies in Economic History of the Middle East. Oxford University Press, London, pp. 428-467.

Marshall, M.G., Jaggers, K., 2016. Polity IV Project: Political Regime Characteristics and Transitions, 1800-2015 [WWW Document]. http://www.systemicpeace. org/inscrdata.html.

Menaldo, V., 2016. The Institutions Curse: Natural Resources, Politics, and Development. Cambridge University Press, Cambridge, U.K., New York.

Munck, G.L., Verkuilen, J., 2002. Conceptualizing and measuring democracy: evaluating alternative indices. Comp. Polit. Stud. 35, 5-34.

Prichard, W., Cobham, A., Goodall, A., 2014a. The ICTD Government Revenue Datase [WWW Document] (accessed 24 August 2016). http://www.ictd.ac/datasets/ the-ictd-government-revenue-dataset.

Prichard, W., Salardi, P., Segal, P., 2014b. Taxation, Non-tax Revenue and Democracy: New Evidence Using New Cross-country Data. ICTD Working Paper 23.

Ramsay, K.W., 2011. Revisiting the resource curse: natural disasters, the price of oil, and democracy. Int. Organ. 65, 507-529. http://dx.doi.org/10.1017/ S002081831100018X.

Ross, M.L., 2006. Is democracy good for the poor? Am. J. Political Sci. 50, 860-874.

Ross, M.L., 2012. The Oil Curse: How Petroleum Wealth Shapes the Development of Nations. Princeton University Press.

Ross, M.L., 2015. What have we learned about the resource curse? Annu. Rev. Political Sci. 18, 239-259. http://dx.doi.org/10.1146/annurev-polisci-052213040359.

Ross, M.L., Mahdavi, P., 2015. Oil and Gas Data, 1932-2014 [WWW Document] Harvard Dataverse (accessed 22 August 2016). http://dx.doi.org/10.7910/DVN/ ZTPWOY.

Soares, R., 2005. Mortality reductions, educational attainment, and fertility choice Am. Econ. Rev. 95, 580-601.

UCDP/PRIO, 2015. UCDP/PRIO Armed Conflict Dataset, V.4-2015 [WWW Document] (accessed 26 August 2016). http://www.pcr.uu.se/research/ucdp/ datasets/ucdp_prio_armed_conflict_dataset/.

UN Inter-Agency Group for Child Mortality Estimation (IGME), 2016. Child Mortality Estimates [WWW Document]. http://www.childmortality.org/.

van der Ploeg, F., 2011. Natural resources: curse or blessing? J. Econ. Literature 49 366-420.

Wacziarg, R., 2012. The first law of petropolitics. Economica 79, 641-657. http:// dx.doi.org/10.1111/j.1468-0335.2011.00902.x.

Wenar, L., 2016. Blood Oil: Tyrants, Violence, and the Rules that Run the World. Oxford University Press, New York, NY.

Yazbeck, A.S., 2009. Attacking Inequality in the Health Sector. World Bank, Washington D.C. 